\title{
PERANCANGAN DAN IMPLEMENTASI MODEL PENGEMBANGAN ENTREPRENEUR INDUSTRI KREATIF PADA PERGURUAN TINGGI BERBASIS PENDIDIKAN VOKASIONAL
}

\author{
Afridian Wirahadi Ahmad \\ Eka Rosalina \\ Jurusan Akuntansi, Politeknik Negeri Padang
}

\begin{abstract}
ABSTRAK
One of the obstacles faced in the development of creative industry is related to the human resources qualification. Although the higher education is believed as the main supplier of entrepreneurs, the existing enterpreneurship course does not support the development of creative industry. Therefore, this study aims to investigate entrepreneurships characters among accounting students at the Padang State Polytechnic. This study found that majority of the students claimed that they know creative industry very well. Meanwhile, the current curriculum is more theoretical based than practical oriented. This study, therefore, suggests developing enterprenership course based on five minds of future.
\end{abstract}

Key words: Creative industry, curriculum, development model

\section{Latar Belakang}

Pembentukan Kementerian Pariwisata dan Ekonomi Kreatif serta telah disusunnya Rencana Pengembangan Ekonomi Kreatif Indonesia 2025 merupakan salah satu bukti nyata dukungan pemerintah terhadap industri kreatif di Indonesia. Disamping itu, kolaborasi antara pemerintah, akademisi dan bisnis menjadi mutlak dan merupakan prasyarat mendasar (Departemen Perdagangan RI, 2008) untuk mewujudkan visi ekonomi kreatif Indonesia 2025 yaitu "Bangsa Indonesia yang berkualitas hidup dan bercitra kreatif di mata dunia".

Menurut

Departemen

Perdagangan RI (2008), salah satu permasalahan utama dalam pengembangan industri kreatifadalah dalam hal kualitas dan kuantitas sumber daya manusia sebagai pelaku dalam industri kreatif, yang membutuhkan perbaikan dan pengembangan. Perguruan tinggi, terutama yang berada pada jalur vokasional diharapkan mampu dalam mengatasi permasalahan ini melalui kurikulum yang aplikatif dan kompetitif. Disamping itu, pembentukan karakter kewirausahaan melalui penanaman pola pikir yang lebih kontekstual dan kreatif sangat penting artinya mengingat ekonomi kreatif merupakan wujud dari upaya mencari pembangunan yang berkelanjutan melalui pemanfaatan cadangan sumber daya yang bukan hanya terbarukan, bahkan tak terbatas yaitu ide, talenta dan kreatifitas.

Partisipasi kaum muda dalam aktivitas ekonomi khususnya dan pembangunan ekonomi pada umumnya mempunyai peran yang sangat penting, karena lebih dari separuh penduduk Indonesia adalah berusia muda. Jika kuantitas dan kualitas sumber daya insani sebagai pelaku dalam industri kreatif dapat dapat ditingkatkan maka satu dari lima permasalahan utama yang menjadi pokok perhatian dalam rencana pengembangan industri kreatif untuk pencapaian tahun 2015 dapat teratasi sehingga visi ekonomi kreatif Indonesia 2025 dapat tercapai.

Industri kreatif adalah penghasil creative capital. Dengan merangsang industri kreatif di Indonesia, industriindustri lokal bisa mengurangi ketergantungan industri manufaktur 
dalam hal pembayaran pembayaran lisensi-lisensi terhadap produk asing.

Walaupun beberapa perguruan tinggi telah memasukkan mata kuliah kewirausahaan dalam kurikulumnya.Namun hasil dari penerapan kurikulum ini belum terlihat secara signifikan.Hal ini salah satunya disebabkan karena kurikulum yang ada saat ini pendekatannya lebih kepada teori, sehingga membosankan dan gagal menumbuhkembangkan potensi kewirausahaan yang dimiliki anak didik.Kurikulum yang merupakan salah satu output dari model dalam penelitian ini untuk menggunakan pendekatan kemampuan kognisi, yang dikenal dengan teori kemajemukan yang dikembangkan oleh Howard Gardner. Dalam konsep ini, kurikulum yang dihasilkan akan menghasilkan 5 pola pikir utama yang diperlukan dimasa mendatang yakni (1) pola pikir disipliner (the disciplinary mind), (2) pola pikir mensintesa (the synthesizing mind), (3) pola pikir kreasi (the creating mind), (4) pola pikir penghargaan (respectful mind), dan (5) pola pikir etis (ethical mind). Pola pikir tersebut merupakan pola pikir yang sangat diperlukan untuk tetap tumbuh berkembang serta bertahan dimasa mendatang. Sehingga dapat disimpulkan bahwa untuk menjadi pekerja kreatif tidaklah cukup memiliki bakat pandai menggambar, menari, menyanyi, dan menulis cerita. la harus mampu memiliki kemampuan mengorganisasikan ide-ide multi disipliner dan juga kemampuan memecahkan masalah dengan caracara diluar kebiasaan.
Politeknik sebagai lembaga pendidikan vokasional merupakan tempat yang tepat untuk pengembangan model ini ke depan. Hal ini disebabkan karena pendekatan aktivitas praktek kerja lebih besar daripada porsi kuliah secara teori. Dengan demikian, upaya membentuk 5 pola pikir utama bagi aktivitas pembelajaran dalam rangka memaksimalkan sektor industri kreatif dari kalangan perguruan tinggi, diharapkan akan terwujud dengan penggunaan model kurikulum yang tepat.

\section{Studi Literatur}

Ekonomi kreatif merupakan manifestasi dari semangat bertahan hidup yang sangat penting bagi negara- negara maju dan juga menawarkan peluang yang sama untuk negara-negara berkembang. Peran besar yang ditawarkan ekonomi kreatif adalah pemanfaatan sumber daya yang bukan hanya terbarukan, bahkan tak terbats, yaitu ide, talenta dan kreatifitas (Departemen Perdagangan RI, 2008).

\section{Model Pengembangan Industri Kreatif}

Model pengembangan industri kreatif adalaah layaknya sebuah bangunan yang akan menguatkan industri Indonesia, dengan landasan, pilar dan atap sebagai elemen bangunan tersebut, seperti tergambar dalam gambar 1. berikut:

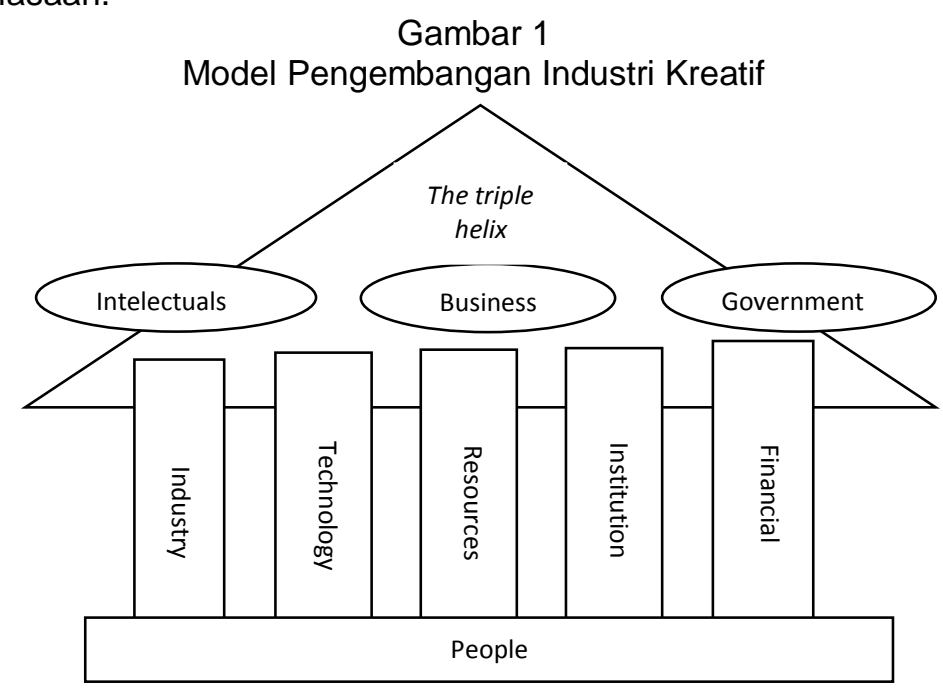


Pondasi industri kreatif adalah sumber daya insani (people) indonesia yang merupakan elemen terpenting dalam industri kreatif. Keunikan industri kreatif adalah peran sentral sumberdaya insani dibandingkan dengan faktor produksi lainnya.

\section{Watak dan Karakter Wirausahawan}

Kewirausahaan adalah semangat, sikap, perilaku kemampuan seseorang dalam menangani usaha atau kegiatan yang mengarah pada upaya mencari, menciptakan, menerapkan cara kerja, teknologi dan produk baru dengan meningkatkan efisiensi dalam rangka memberikan pelayanan yang lebih baik dan atau memperoleh keuntungan yang lebih besar (Drucker, 1985)

(1996), ciri-ciri dan watak kewirausahaan adalah:

Tabel 1

Ciri-ciri dan watak kewirausahaan

\begin{tabular}{|l|l|}
\hline \multicolumn{1}{|c|}{ Karakteristik } & \multicolumn{1}{c|}{ Watak } \\
\hline Percaya diri dan optimis & $\begin{array}{l}\text { Memiliki kepercayaan diri yang kuat, tidak tergantung pada } \\
\text { orang lain dan individualistis }\end{array}$ \\
\hline $\begin{array}{l}\text { Berorientasi pada tugas dan } \\
\text { hasil }\end{array}$ & $\begin{array}{l}\text { Kebutuhan untuk berprestasoi, orientasi laba, enerjik, trekun, } \\
\text { tabah, pekerja keras dan inisyatif }\end{array}$ \\
\hline $\begin{array}{l}\text { Berani megambil risiko dan } \\
\text { menyukai tantangan }\end{array}$ & Mampu mengambil risiko yang wajar \\
\hline Kepemimpinan & Berjiwa pemimpin, mampu beradaptasi dengan baik dan kritis \\
\hline Keorisinilan & Inovatif, ktreatif dan fleksibel \\
\hline Berorientasi masa depan & Memiliki visi kedepan \\
\hline
\end{tabular}

\section{Metode Penelitian Sifat dan Tahapan Penelitian}

Penelitian ini secara keseluruhan bersifat kualitatif. Tahap pertama dalam penelitian ini adalah tahap pemetaan dalam menghasilkan kurikulum pendidikan kewirausahaan pada industri kreatif berbasis pendidikan vokasional. Untuk mendapatkan kurikulum tersebut akan dilakukan studi empiris dalam mengidentifikasi faktor-faktor yang akan mempengaruhi keberhasilan kurikulum tersebut. Riset ini akan dilakukan terhadap the triple helix yang akan menentukan keberhasilan pelaksanaan kurikulum ini yakni akademisi, pelaku bisnis dan pemerintah. Hasil yang diperoleh adalah adanya kurikulum berbasis industri kreatif. Kurikulum yang dihasilkan akan dilakukan dengan berbagai pendekatan yang tepat sesuai dengan kurikulum diantaranya yakni (1) Teknik ceramah bervariasi (2) Teknik Permainan (3) Teknik Kerja Kelompok (4) Teknik simulasi (5) teknik praktek lapangan.

\section{Variabel Penelitian}

Variabel utama yang akan diamati dalam penelitian ini adalah:

1. Karakteristik individu

2. Karakteristik potensi ekonomi dan entrepeneur di lihat dari minat dan keberanian untuk melakukan usaha sesuai dengan menyusun daftar pertanyaan untuk menditeksi potensi karakteristik entrepeneur sesuai dengan konsep teoritis.

3. Karakteristik industri kreatif

4. Karakteristik pola pikir

5. Karakteristik pendidikan vokasional

Populasi dari studi ini adalah akademisi, pelaku bisnis industri kreatif dan pemerintah yang bertanggungjawab dalam pengembangan industri kreatif. Menurut Sakaran (2000), pada penelitian kwalitatif formula untuk menentukan jumlah sampel yang akan diambil dari populasi tidak dapat dijadikan acuan dalam penentuan jumlah sampel. Hal ini disebabkan oleh pentingnya penggalian informasi 
sehingga jumlah sampel dapat ditetapkan oleh peneliti sesuai kondisi penelitian dan tujuan yang akan dicapai. Namun demikian, untuk penentuan jumlah sampel penelitian digunakan formula yang dikemukakan oleh Rao (1996), adapun formula penentuan sampling Dengan tingkat kepercayaan $90 \%$, maka MOE adalah $10 \%$, nilai $Z$ tabel adalah 1,96 , sehingga diperoleh nilai $\mathrm{N}$ sebagai berikut:

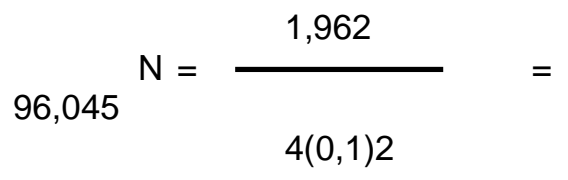

Berdasarkan perhitungan ini maka sampel ditentukan minimal sebanyak 100 orang. Dengan mempertimbangkan kendala waktu, biaya dan tenaga serta upaya penggalian informasi seoptimal mungkin, maka dalam studi ini ditetapkan sampel penelitian diambil dengan teknik purposive cluster random sampling, dengan jumlah sampel sebanyak 214 orang responden mahasiswa untuk mengukur dimensi sifat entrepreneur. Selain itu penelitian ini juga akan mengambil sampel untuk menggali informasi yang berasal dari triple helix yakni berasal dari 11 orang tim dosen pengasuh mata kuliah kewirausahaan, 35 pelaku bisnis industri kreatif yang berasal dari Padang, Bukittinggi, Jakarta dan Bali dan 3 orang pejabat pemerintah dari berbagai instansi yang bertanggungjawab dalam pengembangan industri kreatif yakni Dinas Pariwisata dan Ekonomi Kreatif Propinsi Sumatera Barat.

\section{Hasil Penelitian dan Pembahasan Dimensi karakteristik Potensi Entrepreneur}

Identifikasi perkembangan tingkat Entrepreneur responden telah diukur dengan menggunakan beberapa dimensi yang mencakup:

a. Disiplin

b. Dorongan dan keinginan untuk maju

c. Menghadapi resiko

d. Kepercayaan Diri

e. Kreatifitas

f. Kebebasan dalam bertindak

Berdasarkan kepada nilai rata rata terhadap jawaban pertanyaan yang diajukan kepada 214 responden, menunjukan tingkat entrepreneurship responden mahasiswa yang diteliti berada pada skala 4,6 dari skala 7 . Nilai ini menunjukan bahwa sifat entrepreneurship yang dimiliki oleh responden masih jauh dari idealnya, namun setidaknya angka tersebut tidak terlalu rendah atau berada pada titik tengah. Dengan demikian dapat dikatakan bahwa responden memiliki potensi sikap entrepreneurship, hal yang perlu dilakukan adalah melakukan peningkatan dan pengembangan sifat ini. Pada tabel 5.7 berikut dapat dilihat ringkasan nilai masing dimensi yang digunakan mengukur sifat entrepreneurship

Tabel 2

Ringkasan Nilai Dimensi Sifat Entrepreneurship Responden Penelitian

\begin{tabular}{|c|c|c|c|c|c|c|}
\hline & \multicolumn{5}{|c|}{ Dimensi } \\
\cline { 2 - 7 } & Kebebasan & Disiplin & Kretifitas & Dorongan & $\begin{array}{c}\text { Menghadapi } \\
\text { resiko }\end{array}$ & $\begin{array}{c}\text { Kepercaya } \\
\text { diri }\end{array}$ \\
\hline $\begin{array}{c}\text { Jumlah } \\
\text { sampel }\end{array}$ & 214 & 214 & 214 & 214 & 214 & 214 \\
\hline $\begin{array}{c}\text { Rata } \\
\text { Rata }\end{array}$ & 4,08 & 4,95 & 4,77 & 4,96 & 5,03 & 4,37 \\
\hline
\end{tabular}

Sumber: Data Lapangan, diolah, 2013 
Berdasarkan pada Tabel 2 di atas, maka terlihat dari enam dimensi yang digunakan untuk menilai tingkat entrepreneurship nilai rata rata yang cukup tinggi dimiliki oleh responden adalah menghadapi resiko $(5,03)$, dikuti oleh dimensi keinginan dan dorongan untuk maju (4,96). Nilai dimensi berikutnya adalah disiplin $(4,95$, diikuti oleh tingkat kreatifitas $(4,77)$, tingkat kepecayaan diri $(4,37)$, dan Kebebasan (4,08). Berikut adalah analisis terhadap dimensi yang dinilai pada sifat entrepreneusrhip responden berdasarkan urutan nilai survei.

\section{Keinginan Menghadapi Resiko}

Nilai rata-rata untuk keinginan menghadapi resiko adalah 5,035 yang mana nilai ini menunjukan bahwa responden telah memiliki keinginan mengambil resiko dalam kehidupan mereka walau angka ini masih cukup jauh dari nilai maksimum yaitu 7.Namun setidaknya dari angka ini telah memberi gambaran bahwa responden memiliki keinginan mengambil resiko. Dalam kaitan dengan keinginan untuk menjalankan usaha, keberadaan sifat pengambilan resiko sangat penting.

Beberapa penulis malah beranggapan bahwa faktor pengambilan resiko inilah yang paling besar perannya dalam mendorong seseorang dalam menjalankan usaha atau menjadi seorang entrepreneur.Dimensi berani menghadapi resiko ini menjadi yang tertinggi disebabkan karena responden masih berusia muda, tidak memiliki tanggungan dan keberanian untuk mencoba sesuatu yang baru.Responden cenderung ingin mencoba hal-hal yang baru dalam kehidupannya dan berani gagal karena dianggap hal baru itu memberikan tantangan.

\section{Keinginan dan dorongan untuk maju \\ Keinginan dan dorongan untuk maju merupakan dimensi yang mendapat nilai tinggi kedua setelah keberanian menghadapi resiko yaitu sebesar 4,964. Sama juga halnya dengan keberanian menghadapi resiko,}

kebaradaan dimensi ini menunjukan responden telah memiliki hasrat dan keinginan untuk maju dan berubah dari apa yang dialami saat ini. Namun perlu perlakuan yang tepat agar mereka dapat mengeksploitasi potensi yang ada. Tentunya dengan ada intervensi untuk menghadapi hambatan-hambatan yang ada tentunya kemauan untuk maju ini akan lebih kuat sehingga mereka akan mampu memecahkan persoalan kemiskinan yang ada saat ini.

\section{Disiplin}

Disiplin merupakan salah satu sifat penting sebagai seorang entrepreneurs, orang yang disiplin berarti orang tersebut akan berkomitmen untuk mematuhi dan mengikuti berbagai hal telah dicetuskan. Penelitian ini menunjukkan bahwa responden yang diteliti memiliki disiplin yakni di tingkat 4,955 (skala 7). Hal ini bermakna dalam melaksanakan kegiatan wirausahawan yang disiplin akan memiliki dan menjaga komitmen terhadap tugas dan pekerjaan secara menyeluruh antara lain ketepatan terhadap waktu, peningkatan kualitas pekerjaan, dan sistem kerja. Dengan kedisiplinan terhadap komitmen, wirausahawan akan selalu berupaya meningkatkan kualitas pekerjaan dan membangun keunggulan daya saing. Dalam hal memiliki komitmen tinggi berarti si pengusaha menepati kesepakatan mengenai sesuatu hal yang dibuat, baik terhadap dirinya sendiri maupun orang lain. Dalam melaksanakan kegiatan, wirausahawan akan memiliki komitmen yang konkret, terarah, dan progresif (berorientasi pada kemajuan).

\section{Kreatifitas}

Wirausahawan juga harus memiliki daya kreativitas tinggi yang dilandasi oleh cara berpikir yang maju dengan gagasan baru yang inovatif. Gagasan kreatif tidak dapat dibatasi oleh ruang, bentuk, ataupun waktu.Justru sering kali ide jenius memberi terobosan baru dalam dunia usaha yang awalnya dilandasi oleh berbagai gagasan kreatif yang kelihatannya mustahil. Dalam industri kreatif, kreatifitas 
sebenarnya modal paling utama bergelut dalam bidang ini, namun demikian dalam penelitian dimensi kreatifitas termasuk nilai yang rendah adalah 4,778 atau dibawah angka rata rata dan dibandingkan dengan dimensi lain, tingkat kreatiftas menduduki peringkat keempat dari 6 . Rendahnya nilai bisa saja disebabkan oleh berbagai faktor termasuk diantaranya adalah sistim pendidikan selama ini, sosial budaya dan keluarga.

Responden dalam hal ini tidak berani untuk mempertanyakan hal hal yang telah berlangsung dan mereka cenderung untuk menerima apa yang sudah berlaku, tidak ada keberanian untuk melihat sesuatu yang berbeda sebab mereka yang berbeda akan dianggap salah. Namun kondisi ini bukan kondisi ideal untuk berusaha, dalam berusaha atau dalam bisnis. Salah satu faktor penentu kesuksesan adalah adanya kemampuan untuk menghasilkan atau menawarkan sesuatu yang berbeda dengan apa yang telah ada dipasar atau dengan apa yang telah dihasilkan oleh pesaing. Kemampuan untuk menghasilkan dan menawarkan suatu yang baru dan unik dari apa yang telah ada dan keunikan tersebut menambah dan meningkatkan nilai tambah bagi konsumen, adalah merupakan suatu keunggulan yang harus dikembangkan setiap saat oleh pengusaha.

\section{Kepercayaan Diri}

Dimensi kepercayaan diri responden dengan nilai 4,371 menunjukan bahwa responden penelitian ini memiliki tingkat kepercayaan diri di atas ratarata (3.5). Kepercayaan diri dalam berusaha sangat penting, dengan kepercayaan diri maka pengusaha akan melakukan segala sesuatu dengan penuh keyakinan dan tidak ragu ragu. Walau angka ini tidak terlalu tinggi tetapi juga tidak terlalu rendah artinya responden yang diteliti setidaknya memiliki dasar rasa percaya diri dan mungkin bisa ditingkatkan melalu berbagai intervensi atau treatment.

\section{Kebebasan}

Dimensi ini merupakan dimensi yang nilai paling rendah dari dimensi yang lain yaitu 4,08. Dalam dimensi ini kebebasan diartikan sejauh mana responden mau dan mampu untuk terus mengekspresikan ide dan menjalankan aktifitasnya mereka secara independen. Rendahnya nilai ini berkaitan dengan kondisi sosial budaya yang tidak memupuk seseorang untuk mandiri dan independen. Hal ini bisa saja disebabkan oleh karena lingkungan keluarga terlalu memberi perlindungan pada anggotanya sehingga pada akhirnya akan timbul rasa tidak percaya diri untuk berbuat dan akan dependen pada orang lain. Faktor ini menjadi penentu kekhasan dari seorang entrepreneur. Selain keinginan yang tidak ingin ditentukan oleh orang lain, keinginan untuk independen akan memicu seorang entrepreneur menghasilkan produk yang berbeda dengan orang lain. la akan lebih berani dalam membuat keputusan sendiri dalam mengeksploitasi peluang berwirausaha.

\section{Model Pengembangan Kurikulum Entrepreneurship berbasis industri kreatif dan pendidikan vokasional}

Salah satu persoalan paling mendasar saat ini dalam pengembangan industri kreatif adalah keterbatasan sumber daya manusia atau pelaku usaha yang mau dan mampu bergerak dalam bidang industri kreatif. Hal ini salah satunya disebabkan karena supply sumber daya manusia yang berkualitas dari perguruan tinggi tidak berhasil menumbuhkan minat berwirausaha bagi mahasiswanya. Dari hasil FGD dan wawancara dengan pelaku usaha dan pengajar kewirausahaan diperoleh hasil bahwa orientasi materi kurikulum lebih berbasis pada pengetahuan dan teori belaka dan tidak berorientasi pada tindakan serta menggali dan meningkatkan sifat-sifat wirausaha itu sendiri khususnya terkait dengan industri kreatif.

Selain itu mata kuliah kewirausahaan cenderung membosankan karena dosen lebih pada teks book. Dosen lebih mengedepankan teori-teori yang ada tanpa menumbuhkembangkan agar 
siswanya tertarik, tahu apa yang harus dilakukan, berani mengambil resiko dan mulai bergerak berusaha.

Berdasarkan hasil penelitian yang telah dilakukan, maka berikut dikemukakan model pengembangan kurikulum entrepreneur industri kreatif pada pendidikan tinggi berbasis vokasional.

Tabel 3

Rencana Kegiatan Pembelajaran Mingguan (RKBM)

\begin{tabular}{|c|c|c|}
\hline Minggu ke & Topik (Pokok Bahasan) dan catatan penting & Metode Pembelajaran \\
\hline 1 & $\begin{array}{l}\text { Menjadi Wirausaha } \\
\text { Catatan: Pertemuan pertama adalah pembuka, instruktur } \\
\text { diharapkan memberikan ilustrasi yang menarik dan } \\
\text { mudah dicerna. Mahasiswa tidak boleh diminta } \\
\text { menerangkan secara detail idenya karena sebagai } \\
\text { pemula masih gagap dan ragu-ragu }\end{array}$ & $\begin{array}{l}\text { 1. Ceramah dan } \\
\text { diskusi } \\
\text { 2. Tugas Lapangan } \\
\text { berupa mendeteksi } \\
\text { bisnis spekulatif } \\
\text { 3. Tugas lapangan } \\
\text { memikirkan usaha } \\
\text { baru }\end{array}$ \\
\hline 2 & $\begin{array}{l}\text { Berpikir Perubahan } \\
\text { Catatan: instruktur memberikan tugas agar mahasiswa } \\
\text { mampu memahami pentingnya perubahan dan peranan } \\
\text { mindset (pola pikir) dan mampu mengenal mindset } \\
\text { entrepreneur dan kecerdasan finansial }\end{array}$ & $\begin{array}{l}\text { 1. Ceramah dan } \\
\text { diskusi } \\
\text { 2. Games }\end{array}$ \\
\hline 3 & $\begin{array}{l}\text { Industri Kreatif } \\
\text { Catatan: instruktur menjelaskan karakteristik industry } \\
\text { kreatif yakni industry yang berbasis pada energy } \\
\text { terbarukan dan tak terbatas dan berbasis pada manusia }\end{array}$ & 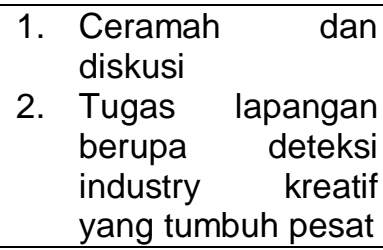 \\
\hline 4 & $\begin{array}{l}\text { Berpikir kreatif } \\
\text { Catatan: Instruktur harus mampu menjelaskan bahwa } \\
\text { kreatifitas adalah modal sangat penting bagi } \\
\text { wirausahawan dan mengenal cara meningkatkan } \\
\text { kreatifitas serta membebaskan diri dari belenggu. Industri } \\
\text { kreatif berbasis pada kreatifitas karena kreatifitas tidak } \\
\text { pernah mati }\end{array}$ & 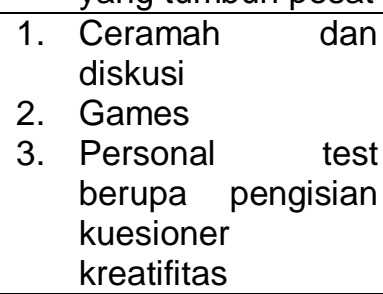 \\
\hline 5 & $\begin{array}{l}\text { Berorientasi pada tindakan } \\
\text { Catatan: sifat wirausaha ini syarat wajib dimiliki oleh } \\
\text { seorang wirausahawan agar tidak menjadi orang yang } \\
\text { ragu-ragu dan takut memulai }\end{array}$ & 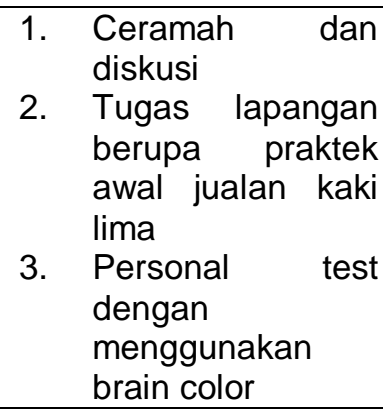 \\
\hline 6 & $\begin{array}{l}\text { Pengambilan resiko } \\
\text { Catatan: Instruktur harus mampu mengarahkan peserta } \\
\text { mengenal konsep resiko dan mampu mengidentifikasi } \\
\text { resiko yang akan timbul. Instruktur juga harus } \\
\text { mengarahkan pada peserta bahwa resiko perlu } \\
\text { diperhitungkan, namun bukan untuk dihindari, melainkan } \\
\text { untuk "dijinakkan" }\end{array}$ & $\begin{array}{l}\text { Ceramah dan } \\
\text { diskusi } \\
\text { Games berupa } \\
\text { permainan } \\
\text { pengambilan } \\
\text { resiko }\end{array}$ \\
\hline 7 & $\begin{array}{l}\text { Kepemimpinan } \\
\text { Catatan: instruktur akan mengarahkan mahasiswa } \\
\text { mampu membedakan manajer dengan pemimpin, serta }\end{array}$ & $\begin{array}{ll}\text { 1. } & \begin{array}{l}\text { Ceramah } \\
\text { diskusi }\end{array} \\
\text { 2. } & \text { Pemutaran }\end{array}$ \\
\hline
\end{tabular}




\begin{tabular}{|c|c|c|}
\hline & menjelaskan teori kepemimpinan & $\begin{array}{l}\text { kisah seorang } \\
\text { wirausaha muda } \\
\text { 3. Personal test } \\
\text { yakni mama-reptil } \\
\text { yang } \\
\text { dikembangkan } \\
\text { oleh B.Joseph } \\
\text { White }\end{array}$ \\
\hline 8 & $\begin{array}{l}\text { Etika Bisnis } \\
\text { Catatan:Instruktur mengarahkan peserta memahami } \\
\text { teknik menciptakan bisnis dengan etika baik dan } \\
\text { bagaimana hubungan antara etika bisnis dengan } \\
\text { perkembangan usaha di jangka panjang }\end{array}$ & $\begin{array}{ll}\text { 1. } & \begin{array}{l}\text { Ceramah dan } \\
\text { diskusi }\end{array} \\
\text { 2. } & \text { Bedah kasus }\end{array}$ \\
\hline 9 & Ujian tengah semester & \\
\hline 10 & $\begin{array}{l}\text { Faktor "X" dalam bisnis } \\
\text { Catatan: Instruktur mengarahkan mahasiswa memahami } \\
\text { pengertian faktor ' } X \text { ", menemukan, menggali dan } \\
\text { menjelaskan sikap dalam menghadapi faktor " } \mathrm{X} \text { ". }\end{array}$ & $\begin{array}{l}\text { 1. Ceramah dan } \\
\text { diskusi } \\
\text { 2. Tugas lapangan } \\
\text { yakni mendeteksi } \\
\text { faktor } X\end{array}$ \\
\hline 11 & $\begin{array}{l}\text { Mencari gagasan usaha industry kreatif } \\
\text { Catatan: instruktur menjelaskan cara-cara mencari } \\
\text { gagasan baru dan menjelaskan bidang industry kreatif }\end{array}$ & 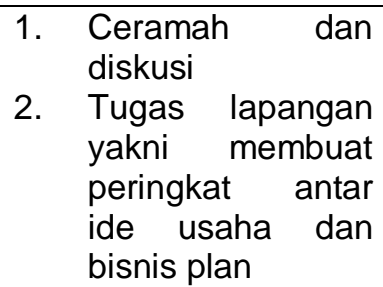 \\
\hline 12 & $\begin{array}{l}\text { Pemasaran usaha secara kreatif } \\
\text { Catatan: instruktur menjelaskan konsep manajemen dan } \\
\text { strategi bauran pemasaran }\end{array}$ & $\begin{array}{ll}\text { 1. } & \begin{array}{l}\text { Ceramah dan } \\
\text { diskusi }\end{array} \\
\text { 2. } & \text { Bedah kasus } \\
\end{array}$ \\
\hline 13 & $\begin{array}{l}\text { Manajemen keuangan usaha } \\
\text { Catatan: instruktur menjelaskan sumber-sumber } \\
\text { pendanaan dan pentingnya manajemen keuangan usaha }\end{array}$ & $\begin{array}{ll}\text { 1. } & \begin{array}{l}\text { Ceramah dan } \\
\text { diskusi }\end{array} \\
\text { 2. } & \text { Bedah kasus }\end{array}$ \\
\hline 14 & $\begin{array}{l}\text { Studi banding ke beberapa usaha industry kreatif } \\
\text { Catatan: instruktur membawa peserta melihat secara } \\
\text { langsung ke industry kreatif yang ada di kota setempat }\end{array}$ & 1. Diskusi \\
\hline 15 & $\begin{array}{l}\text { Magang } \\
\text { Catatan: pserta diwajibkan magang pada salah satu } \\
\text { tempat usaha yang bergerak di industry kreatif. Selama } \\
\text { magang diharapkan siswa mampu mempelajari aspek } \\
\text { bisnis industry kreatif }\end{array}$ & 2. Praktek lapangan \\
\hline 16 & Memulai usaha baru & $\begin{array}{l}\text { 1. Ceramah } \\
\text { 2. Tugas lapangan } \\
\text { membuat bisnis } \\
\text { plan }\end{array}$ \\
\hline $17-18$ & $\begin{array}{l}\text { Presentasi bisnis plan } \\
\text { Catatan: mahasiswa mempresentasikan bisnis plan } \\
\text { iindustri kreatif yang mereka usulkan }\end{array}$ & 1. diskusi \\
\hline & UAS & \\
\hline
\end{tabular}


Materi tersebut diatas dirancang dengan pendekatan 5 pola pikir yang dibutuhkan dalam pengembangan industry kreatif yakni disipliner, mensintesa, kreasi, penghargaan dan etis.Agar memudahkan dosen dalam memberikan pelajaran, penelitian ini juga telah membuat modul ajar untuk setiap pertemuan nantinya.

\section{Kesimpulan}

1. Salah satu permasalahan utama dalam pengembangan industri kreatif adalah dalam hal kualitas dan kuantitas sumber daya manusia sebagai pelaku dalam industri kreatif, yang membutuhkan perbaikan dan pengembangan.Perguruan tinggi adalah supply pelaku kewirausahaan.

2. Saat ini belum terdapat model pengembangan industry kreatif pada pendidikan vokasional. Penelitian ini menggunakan five minds of future dalam mengubah karakter kewirausahaan melalui penanaman pola pikir yang lebih kontekstual dan kreatif karena mengingat ekonomi kreatif merupakan wujud dari upaya mencari pembangunan yang berkelanjutan melalui pemanfaatan cadangan sumber daya yang bukan hanya terbarukan, bahkan tak terbatas yaitu ide, talenta dan kreatifitas. Pendekatan lainnya adalah inquiry model dalam proses pembelajaran.

3. Mayoritas mahasiswa telah mengenal industri kreatif hal ini terlihat $84,6 \%$ responden tahu dan mengenal industri kreatif dengan baik.

4. Kurikulum yang ada saat ini lebih berbasis pada teori, bukan pada bagaimana

menumbuhkembangkan anak didik agar mereka tertarik, tahu apa yang harus dilakukan, berani mengambil resiko dan mulai bergerak berusaha.

5. Pengukuran dimensi sifat entrepreneur diperoleh hasil dimensi keberanian mengambil resiko memiliki nilai tertinggi
$(5,035)$, dorongan untuk maju $(4,964)$, displin $(4,955)$, kreatifitas $(4,778)$, kepercayaan diri $(4,371)$, kebebasan $(4,087)$.

6. Penelitian ini berhasil merancang model pembelajaran dengan pendekan 5 pola pikir yang dibutuhkan dalam wirausaha di industri kreatif yakni dimulai dengan pendekatan topik menjadi wirausaha, dilanjutkan dengan berpikir perubahan, industri kreatif, berpikir kreatif, berorientasi pada tindakan, pengambilan resiko, kepemimpinan, etika bisnis, faktor " $X$ " dalam bisnis, mencari gagasan usaha industri kreatif, pemasaran usaha secara kreatif, manajemen keuangan usaha, magang dan studi banding ke beberapa industri kreatif, memulai usaha baru dan pembuatan serta presentasi bisnis plan.

\section{Daftar Pustaka}

Amin. Moh, MPd. Panduan Praktis Penelitian Tindakan Kelas Inspirasi, Grobongan. April 2011

Arikunto, S. (1998). Prosedur Penelitian Suatu Pendekatan Praktek. Yogyakarta: Rineka Cipta

Aristiawan, Dwi. Nugroho. Aplikasi Model Pembelajjaran Question student Have Untuk Meningkatkan Keaktivan Bertanya Dan Menjawab Pentanyaan Pada Pelajaran IPA Biologi Siswa SMP

Departemen Pendidikan Nasional.(2002 b). Kegiatan Belajar Mengajar

Departemen Pendidikan Nasional. (2003). Kamus Besar Gahasa Indonesia, Edisi Ketiga, Jakarta: Balai Pustaka

Departemen Perdagangan Republik Indonesia, Pengembangan Ekonomi Kreatif Indonesia, 2025, Jakarta 2008

Daniel L Pink. (2005). A Whole New Mind: berpindah dari jaman informasi menuju jaman konseptual. Jakarta. Penerbit Dinastindo 
Drucker F Peter, Innovation and Enterpreneurship, Practise and principles, 1985

Finkel, E. (2006). A New Literary Hero: Comics Make for Colorful Learning. Diakses pada tanggal 13 juni 2011. Sumber: $<$ http://www.edutopia.org/edfinkel>

Howard Gardner, Five Minds for the future, Ecolint Meeting in Jeneva, January 13, 2008

Irawan, Prasetya dan Prastati, Trini.(1996) Mengajar di Perguruan Tinggi : Program Applied Approach,PAU PPAI UT, Jakarta Irawan, Prasetya dan Prastati, Trini (1996). Mengajar di Perguruan Tinggi;Program Applied approach, PAU PPAI UT, Jakarta

Irfanda Supada. Aminu, S.Pd. M.Pd,. (2010). Pemanfaatan Bahan Ajar Dan Bahan Uji Menggunakan Media Presentasi Pembelajaran Untuk Meningkatkan Pemahaman Siswa Pada Mata Pelajaran Kimia Pokok Bahasan Senyawa Kompleks

Imam Subekti \& Novi Wulandari Widiyanti. Faktor-Faktor Yang Berpengaruh Terhadap audit Delay Di Indonesia

Justin G Longecker, Kewirausahaan, Manajemen Usaha Kecil, Salemb Empat, 2000

Madya, Suwarsih. (2006). Teori dan Praktik Penelitian Tindakan (Action Research). Bandung: Alfabeta

Mas'ud Machfoedz, Kewirausahaan, Suatu Pendekatan Kontemporer, UPP AMP YKPN, Yogyakarta,2004.
Mark, C. (2007). Writing for Animation, comics, and games. Oxford: Focal Press

Prasetyowati, Ari. (2008). Peningkatan Pemahaman Konsep Ingkaran Melalui Implementasi Improving Learning dengan Teknik Inquiry. Surakarta

Richard Florida, The Rise of the Creative Class, New York, 2002

Rita, Setyati Jiwa. Penerapan Pembelajaran Kooperatif Jingsaw Untuk Meningkatkan Keaktivan Belajar Biologi Ditinjau Dari Aspek AKtivitas Langsung. Surakarta

Roestyah.(1998). Strategi Belajar Mengajar, Jakarta:Rineka Cipta

Suryana, Kewirausahaan, Pedoman Praktis: Kiat dan Proses Menuju Sukses Edisi 3, Salemba Empat 2006.

Thacker, C. (2007). How To Use Comic Life in The Classroom. Diakses pada tanggal 24 Februari 2009.

Utomo,Tjipto dan Ruijter,Kees.(1994). Peningkatan dan Pengembangan Pendidikan, Gramedia, Jakarta

Wahyuni, Eka SPd, MAAPD dan Dra Gantina Komalasari,MPsi, Pembelajaran Konseling dengan Program Comic Life

Wegerif, R.(2007).Technology and Dialogic Education:Expanding the Space of Learning Springer Science + Business Media,LLC

Yoni, Acep.SS, dkk.(2010). Menyusun Penelitian Tindakan Kelas, Peningkatan Kemampuan Menulis Melalui Penelitian Tindakan Kelas. Yogyakarta 